\title{
Short Communication: Occurrence and cluster analysis of palm oil (Elaeis guineensis) fruit type using two-dimensional thin layer chromatography
}

\author{
DENI ARIFIYANTO ${ }^{1}$, MOHAMMAD BASYUNI ${ }^{2, \vartheta}$, SUMARDI ${ }^{3}$, LOLLIE AGUSTINA PANCAWARASWATI \\ PUTRI $^{4}$, ETTI SARTINA SIREGAR ${ }^{5}$, IWAN RISNASARI ${ }^{2}$, INDRA SYAHPUTRA ${ }^{1}$ \\ ${ }^{1}$ Graduate School of Agroecotechnology, Faculty of Agriculture, Universitas Sumatera Utara, Medan 20155, North Sumatera, Indonesia \\ ${ }^{2}$ Department of Forestry, Faculty of Forestry, Universitas Sumatera Utara. J1. Tri Dharma Ujung No. 1, Medan 20155, North Sumatera, Indonesia. \\ Tel./Fax: +62-61-820-1920. `email: m.basyuni@usu.ac.id \\ ${ }^{3}$ Faculty of Pharmacy, Universitas Tjut Nyak Dhien, J1. Rasmi No. 28, Medan 20123, North Sumatera, Indonesia \\ ${ }^{4}$ Department of Agroecotechnology, Faculty of Agriculture, Universitas Sumatera Utara. Medan 20155, North Sumatera, Indonesia \\ ${ }^{5}$ Department of Biology, Faculty of Mathematics and Natural Sciences, Universitas Sumatera Utara. Medan 20155, North Sumatera, Indonesia
}

Manuscript received: 1 September 2017. Revision accepted: 27 September 2017.

\begin{abstract}
Arifiyanto D, Basyuni M, Sumardi, Putri LAP, Siregar ES, Risnasari I, Syahputra I. 2017. Short Communication: Occurrence and cluster analysis of palm oil (Elaeis guineensis) fruit type using two-dimensional thin layer chromatography. Biodiversitas 18: 14871492. The problems that have been faced by palm oil breeders are the length of time and high costs to discover the type of palm oil (Elaeis guineensis) fruit namely Dura, Pisifera, or Tenera, before using as a seed parent. These conditions are ineffective and add to the cost of maintenance and the production of seedling is more expensive. The present study describes the occurrence and cluster analysis of palm oil fruits using two-dimensional thin layer chromatography (2D-TLC). The leaves and fruit on each fruit mesocarp and shell, commercial seed on each fruit type were sampled through direct determination, plant nurseries, commercial seed and unknown type of palm oil. 2D-TLC chromatograms of hexane extracts showed diversity in palm oil fruits: Dura had ficaprenol-type polyprenol $\left(\mathrm{C}_{50}-\mathrm{C}_{60}\right)$ and no carbon chain-length of polyprenol and dolichols $\left(\mathrm{C}_{85}-\mathrm{C}_{100}\right)$ were found. In Tenera polyprenols of $\mathrm{C}_{45}-\mathrm{C}_{60}$ and $\mathrm{C}_{90}-\mathrm{C}_{100}$ occurred and dolichols of $\mathrm{C}_{85}-\mathrm{C}_{105}$ as well, where polyprenols of $\mathrm{C}_{45}$ and $\mathrm{C}_{105}$ and dolichol of $\mathrm{C}_{105}$ found in Tenera were not detected in Pisifera. To confirm these findings, cluster analysis was drawn using the UPGMA method. The dendrogram demonstrated that the three types of palm oil were grouped to fruit type, suggesting that the occurrence of polyisoprenoids in palm oil fruits were chemotaxonomically significant.
\end{abstract}

Keywords: Chemotaxonomic marker, Elaeis guineensis, Tenera, Two-Dimensional Thin Layer Chromatography

Abbreviations: 2D-TLC: Two-Dimensional Thin Layer Chromatography, UPGMA: Unweighted-Pair Group Method with Arithmetic mean, MVSP: Multivariate Statistical Package, TL: total lipid, Pol: polyprenol, Dol: dolichol

\section{INTRODUCTION}

Palm oil is one of the main commodities of Indonesia and supplies over 18 million tons of vegetable oil in the world (Oil World 2015). Even though Indonesia is currently the largest producer and exporter of palm oil worldwide, it has still faced problems with the low productivity compared to other countries. High-quality planting material is needed to increase productivity. Determination of fruit type is one of the major problems of palm oil breeders before continuing crossing. At least 5-8 years are required for fruit type identification using conventional methods, which consume time, cost, and labor. Two approaches have been developed by researchers to determinate fruit type (Zhao et al. 2012; Rincon et al. 2013; Ritter et al. 2016). Firstly, the direct determination after the palm oil fruiting, but this way needs a long time to resolve the problems as previously described (Rincon et al. 2013). Secondly, the identification of palm oil fruits using molecular markers (Zhao et al. 2012; Ritter et al. 2016). Nonetheless, there are still issues on molecular markers that cannot differentiate the same fruit type of different origins (Ritter et al. 2016).

Several studies have shown that polysioprenoids can be used as chemotaxonomic markers (Roslinka et al. 2002; Kumari et al. 2013; Basyuni et al. 2016, 2017a). These studies suggest that the chain length of polyisoprenoid alcohol displays a distinct pattern that can be used to differentiate plants into genera and families. It is vital therefore to obtain information on the occurrence of polyisoprenoid in palm oil to determine palm oil fruit type and the chemotaxonomic significance of polyisoprenoids.

Many studies have reported the occurrence of polyisoprenoids from various plants (Ishinaga et al. 1990; Sagami et al. 1992; Kurisaki et al. 1997; Tateyama et al. 1999; Chouda and Jankowski 2005; Basyuni et al. 2016, 2017a). Two primary types of polyisoprenoid alcohols have been described on the OH-terminal $(\alpha-)$ isoprene structure. These include polyprenols ( $\alpha$-unsaturated) and dolichols ( $\alpha$-saturated) compounds (Basyuni et al. 2017). Twodimensional thin layer chromatography (2D-TLC) has been used widely to analyze the polyisoprenoid compound that 
relates to the development phase and different tissues of soybean (Ishinaga et al. 1990, 1992; Kurisaki et al. 1997), rubber and ginkgo (Tateyama et al. 1999), spinach leaves (Sakaihara et al. 2000), mushroom Lentinus edodes (Wojtas et al. 2004), sea fish (Ishiguro et al. 2014), and mangrove plants (Basyuni et al. 2016, 2017a). Despite the chemotaxonomic importance of polyisoprenoids, no information on polyisoprenoid distribution in palm oil has been previously available. The present study describes for the first time the occurrence and tissue distribution of polyisoprenoids in various tissues of palm oil with a particular reference to chemotaxonomic criterion.

\section{MATERIALS AND METHODS}

\section{Chemicals}

The dolichol $\left(\mathrm{C}_{90}-\mathrm{C}_{105}\right)$ and polyprenol $\left(\mathrm{C}_{90}-\mathrm{C}_{100}\right)$ standards were used as previously described (Basyuni et al. 2016, 2017), and used to identify the pattern of polyisoprenoid alcohol that was detected in this study. Silica gel 60 TLC plates and reverse-phase silica RP-18 HPTLC plates were purchased from Merck (Darmstadt, Germany). All of other chemicals and solvents were reagent grade (Merck, Darmstadt, Germany).

\section{Plant materials}

Samples of leaves and fruits from mature palm oils were collected from nurseries. Leaves in front number one (age approximately was 2-4 weeks after opening) were taken as samples from fruit type of Dura (D), Pisifera (P) and Tenera $(\mathrm{T})$ of a mature plant. Leaves from nurseries of an unknown fruit type were also collected in the same manner as previously described. Samples of unknown fruit types of mature plants were also collected from a smallholder area. Fruit samples were gathered from mature fruits (about 5-6 months after pollination) of DxP, and TxT crossing, the mesocarp, and the shell were separated using clean knives. The hard shell was broken into the small pieces using a hammer. All Samples were collected when the average temperature of the environment was $25^{\circ} \mathrm{C}$ and humidity was $83 \%$.

\section{Extraction of polyisoprenoid alcohols}

The procedure of polyisoprenoid alcohol isolation was carried out as previously described (Sagami et al. 1992; Basyuni et al. 2016, 2017a). The samples of leaves, mesocarp of fruits and shells were dried using an oven at $60{ }^{\circ} \mathrm{C}$ for 1-2 days. The dried tissue was crushed into a fine powder using laboratory mills, then $5 \mathrm{~g}$ of each were immersed in chloroform/methanol (CM2:1; v/v), and then incubated in a water bath for $48 \mathrm{~h}$. The supernatant was filtered, then dried using a rotary evaporator. The lipid extract of all samples was saponified at $65^{\circ} \mathrm{C}$ for $24 \mathrm{~h}$ in $86 \%$ ethanol containing $2 \mathrm{M} \mathrm{KOH}$. The non-saponifiable lipids of each sample were evaporated and redissolved in hexane. All the samples extracted (50-100 mg) were applied to each TLC plate.

\section{Investigation of Two-Dimensional Thin Layer Chromatography (2D-TLC)}

First-dimension TLC was carried out on a silica gel glass plate $(20 \times 3 \mathrm{~cm})$ with toluene: ethyl acetate $(9: 1)$ as a solvent for about $45 \mathrm{~min}$ as previously described (Basyuni et al. 2016). The polyprenol compounds will move slightly faster than dolichol family. The longitudinal edge of the first-dimension TLC and the concentration zone of a reverse-phase C-18 TLC were clamped with magnetic bars. The silica gel glass and C-18 (not sure what this means) of TLC plate were then developed in acetone for about 30 minutes to transfer all compounds that has been separated in the first-dimension into concentration zone of the reverse-phase TLC plate. To determine the family of a compound and its concentration, dolichols or polyprenols standards were added to the sample line and developed with a solvent system as previously described. The position of polyisoprenoid alcohol spots that had been developed using 2D-TLC were identified and visualized using iodine vapor. The chromatographic images were scanned using Canon E-400. The polyisoprenoid families pattern were determined by comparing the standard of dolichol or/and polyprenol with the occurrence of polyisoprenoid pattern in TLC samples plate.

The quantification of polyisoprenoid content in samples was carried out by comparing with dolichol and polyprenol standards. A standard curve of concentration of dolichol or polyprenol correlated to iodine-color estimation was drawn. The amount of dolichol and polyprenol were quantified using ImageJ ver. 1.46r (Schneider et al. 1992) in comparison with the standard curve that has been drawn previously.

\section{Cluster analysis}

Cluster analysis was performed on selected subsets of fruit type data consisting of 15 variables, including polyprenols and dolichols from 17 fruit type were log (10) transformed. From these data, dendrogram representing fruit type was drawn by cluster analysis using the unweighted-pair group method with arithmetic mean (UPGMA) and MVSP (multivariate statistical package) 3.22 (Kovach Computing Service). Euclidean distance was chosen as the criterion for cluster combination.

\section{RESULTS AND DISCUSSION}

The identification of fruit type from palm oil was performed by 2D-TLC to separate polyisoprenoids into polyprenol and dolichol families with different chain lengths. The summaries of the analytical results of the distribution of polyisoprenoids in palm oil are given in Table 1. The highest weight of total lipid was from fruit mesocarp ranging from 482-511 $\mathrm{mg} \mathrm{g}^{-1}$ dry weight.The total lipid of leaves samples fluctuated between 20-66 mg $\mathrm{g}^{-1}$ dry weight. Total lipid content in fruits shell or seeds was varied between $26-102 \mathrm{mg} \mathrm{g}^{-1}$ dry weight.

In leaves, the highest total lipid content was Tenera fruit type ranging from 4.5-6.9 $\mathrm{mg} \mathrm{g}^{-1}$ dry weight. On the other hand, Pisifera fruit type had total lipid content of 3.4- 
$4.2 \mathrm{mg} \mathrm{g}^{-1}$ dry weight. Total lipid content in Dura fruit type was the lowest compared to other fruit types, ranging from $3.0-3.8 \mathrm{mg} \mathrm{g}^{-1}$ dry weight. The distribution of polyprenols and dolichols in the plant tissue were classified into three types as previously reported (Basyuni et al. 2016, 2017a). In type-I, dolichol predominated over polyprenol (more than 90\%); type-II displays the occurrence of both polyprenol and dolichol.

In type III, the predominance of polyprenol over dolichol by more than $90 \%$ was detected. Table 1 shows polyisoprenoid pattern in palm oil was only Type-II, without Type-I and-III. The presence of both polyprenols and dolichols agree well with previously reports (Kurisaki et al. 1997; Tateyama et al. 1999). The carbon-chain length of polyisoprenoid in palm oil as shown in Table 2 and Figures 1 and 2 varied according to each tissue even in the same species and formed a particular family with dominant molecule species (Tateyama et al. 1999; Basyuni et al. 2016). Therefore, the samples of this study were collected from the same ages and phases. Thus the composition of the carbon-chain length in each group was consistent and could be identified the differentiation among the fruit type (Tateyama et al. 1999; Basyuni et al. 2016).

Table 1. Distribution of polyprenol and dolichol in palm oil

\begin{tabular}{|c|c|c|c|c|c|c|c|c|c|c|c|c|}
\hline \multirow[t]{2}{*}{ Fruit type } & \multirow[t]{2}{*}{ Origin } & \multirow[t]{2}{*}{ Tissue } & \multirow[t]{2}{*}{ Status } & \multirow{2}{*}{$\begin{array}{c}\text { TL } \\
(\mathrm{mg} / \mathrm{g} \\
\mathrm{dw})\end{array}$} & \multirow{2}{*}{$\begin{array}{c}\text { Pl } \\
(\mathrm{mg} / \mathrm{g} \\
\mathrm{dw})\end{array}$} & \multirow{2}{*}{$\begin{array}{c}\text { Pol } \\
(\mathrm{mg} / \mathrm{g} \\
\mathrm{dw})\end{array}$} & \multirow{2}{*}{$\begin{array}{c}\text { Dol } \\
(\mathrm{mg} / \mathrm{g} \\
\mathrm{dw})\end{array}$} & \multicolumn{3}{|c|}{$\%$ in total lipid } & \multicolumn{2}{|c|}{$\begin{array}{c}\text { \% in } \\
\text { Polyisoprenoid }\end{array}$} \\
\hline & & & & & & & & $\mathbf{P l}$ & Pol & Dol & Pol & Dol \\
\hline$\overline{\text { Dura }}$ & Lame & Leaves & Parent palm & $26 \pm 6.8$ & 3.0 & 1.8 & 1.2 & 11.5 & 6.9 & 4.6 & 60.0 & 40.0 \\
\hline Dura & Angola & Leaves & Parent palm & $49 \pm 3.7$ & 3.3 & 1.9 & 1.4 & 6.7 & 3.9 & 2.9 & 57.6 & 42.4 \\
\hline Dura & Dabou & Leaves & Parent palm & $42 \pm 8.1$ & 3.4 & 2.2 & 1.2 & 8.1 & 5.2 & 2.9 & 64.7 & 35.3 \\
\hline Dura & Unknown & Leaves & Parent palm & $66 \pm 6.6$ & 3.8 & 2.1 & 1.7 & 5.8 & 3.2 & 2.6 & 55.3 & 44.7 \\
\hline Pisifera & Lame & Leaves & Parent palm & $23 \pm 5.4$ & 4.2 & 2.7 & 1.5 & 18.3 & 11.7 & 6.5 & 64.3 & 35.7 \\
\hline Pisifera & Yangambi & Leaves & Parent palm & $49 \pm 3.7$ & 3.6 & 2.5 & 1.1 & 7.3 & 5.1 & 2.2 & 69.4 & 30.6 \\
\hline Pisifera & Unknown & Leaves & - & $37 \pm 4.2$ & 3.4 & 2.1 & 1.3 & 9.2 & 5.7 & 3.5 & 61.8 & 38.2 \\
\hline Tenera & Lame & Leaves & Parent palm & $20 \pm 11.2$ & 5.1 & 3.6 & 1.5 & 25.5 & 18.0 & 7.5 & 70.6 & 29.4 \\
\hline Tenera & Yangambi & Leaves & Parent palm & $41 \pm 11.8$ & 6.9 & 4.9 & 2.0 & 16.8 & 12.0 & 4.9 & 71.0 & 29.0 \\
\hline Tenera & Lame & Leaves & Commercial palm & $34 \pm 4.7$ & 4.5 & 3.2 & 1.3 & 13.2 & 9.4 & 3.8 & 71.1 & 28.9 \\
\hline Dura x Pisifera & Lame & Leaves & Nurseries & $23 \pm 5.4$ & 4.9 & 3.4 & 1.5 & 21.3 & 14.8 & 6.5 & 69.4 & 30.6 \\
\hline Dura $\times$ Pisifera & Lame & $\begin{array}{l}\text { Fruit } \\
\text { mesocarp }\end{array}$ & - & $511 \pm 78.1$ & 3.9 & 2.4 & 1.5 & 0.8 & 0.5 & 0.3 & 61.5 & 38.5 \\
\hline Dura x Pisifera & Lame & Fruit shell & - & $26 \pm 14.1$ & 2.8 & 1.6 & 1.2 & 10.8 & 6.2 & 4.6 & 57.1 & 42.9 \\
\hline Tenera $x$ Tenera & Lame & $\begin{array}{l}\text { Fruit } \\
\text { mesocarp }\end{array}$ & - & $482 \pm 0.0$ & 5.3 & 3.3 & 2.0 & 1.1 & 0.7 & 0.4 & 62.3 & 37.7 \\
\hline Tenera $x$ Tenera & Lame & Fruit shell & - & $102 \pm 0.0$ & 4.7 & 2.8 & 1.9 & 4.6 & 2.7 & 1.9 & 59.6 & 40.4 \\
\hline Unknown & Unknown & Leaves & Smallholders & $27 \pm 1.9$ & 4.4 & 2.7 & 1.7 & 16.3 & 10.0 & 6.3 & 61.4 & 38.6 \\
\hline Unknown & Lame & $\begin{array}{l}\text { Commercial } \\
\text { seed }\end{array}$ & - & $95 \pm 25$ & 4.5 & 2.8 & 1.7 & 4.7 & 2.9 & 1.8 & 62.2 & 37.8 \\
\hline
\end{tabular}

Note: Total lipid are represented as the mean \pm SD $(n \pm 2-3),-:$ unknown, TL: total lipid, Pol: polyprenol, Dol: dolichol

Table 2. Carbon-chain length of polyprenol and dolichol in palm oil*

\begin{tabular}{|c|c|c|c|c|c|c|}
\hline Fruit type & Origin & Tissue & Status & Polyprenol & & Dolichol \\
\hline Dura & Lame & Leaves & Parent palm & 505560 & & 859095100 \\
\hline Dura & Angola & Leaves & Parent palm & 505560 & & 859095100 \\
\hline Dura & Dabou & Leaves & Parent palm & 505560 & & 859095100 \\
\hline Dura & Unknown & Leaves & Parent palm & 505560 & & 859095100 \\
\hline Pisifera & Lame & Leaves & Parent palm & $505560 \ldots$ & 9095100 & 859095100 \\
\hline Pisifera & Yangambi & Leaves & Parent palm & $505560 \ldots$ & 9095100 & 859095100 \\
\hline Pisifera & Unknown & Leaves & - & $505560 \ldots$ & 9095100 & 859095100 \\
\hline Tenera & Lame & Leaves & Parent palm & 45505560 & 9095100105 & 859095100105 \\
\hline Tenera & Yangambi & Leaves & Parent palm & 45505560 . & 9095100105 & 859095100105 \\
\hline Tenera & Lame & Leaves & Commercial & 45505560 & 9095100105 & 859095100105 \\
\hline Dura x Pisifera & Lame & Leaves & Nurseries & 50556065 & 9095100 & 859095100105 \\
\hline Dura x Pisifera & Lame & fruit mesocarp & - & 50556065 & 9095100105 & 859095100105 \\
\hline Dura x Pisifera & Lame & fruit shell & - & $505560 \ldots$ & 9095100 & $859095100105 \quad 110$ \\
\hline Tenera $\times$ Tenera & Lame & fruit mesocarp & - & $505560 \ldots$ & 9095100105 & 859095100105110 \\
\hline Tenera $\times$ Tenera & Lame & fruit shell & - & $505560 \ldots$ & 9095100105 & 859095100105110 \\
\hline Unknown & Unknown & Leaves & Smallholders & 45505560 . & 9095100105 & 859095100105110 \\
\hline Unknown & Lame & Seeds & - & $505560 \ldots$ & 9095100105 & 859095100105110 \\
\hline
\end{tabular}




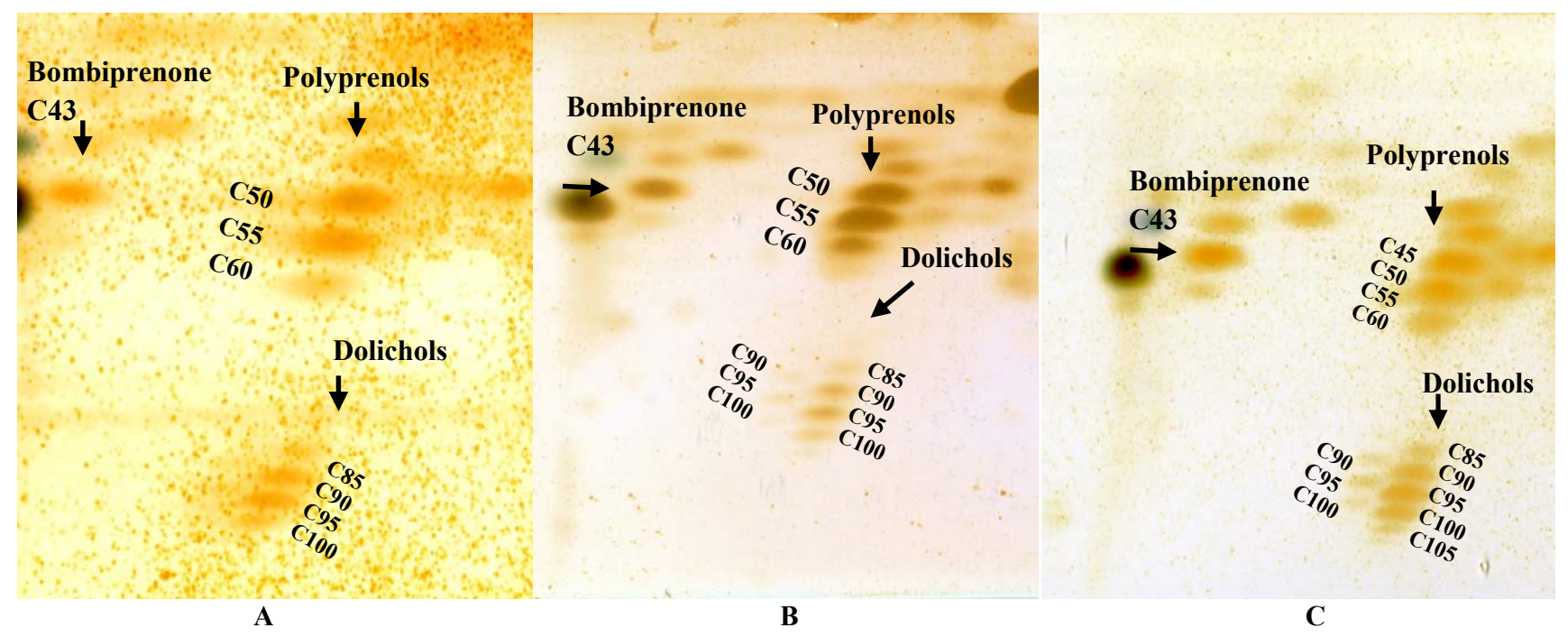

Figure 1. 2D-TLC chromatograms of polyisoprenoids from Dura (A), Pisifera (B), and Tenera (C). The Carbon number refers to the carbon-chain length of polyisoprenoid alcohols. Data are represented as three independent experiments

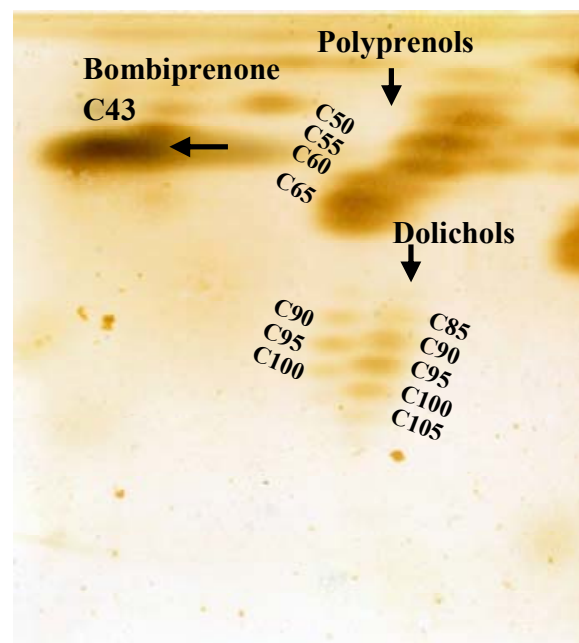

A



B

Figure 2. 2D-TLC chromatograms of polyisoprenoids from nursery DxP (Dura x Pisifera)(A) and fruit shell (B). The Carbon number refers to the carbon-chain length of polyisoprenoid alcohols. Data are represented as three independent experiments

The shorter carbon-chain of polyprenols $\left(\mathrm{C}_{50}-\mathrm{C}_{60}\right)$ and dolichols $\left(\mathrm{C}_{85}-\mathrm{C}_{100}\right)$ occurred in all Dura fruit types (Figure 1A), but long-chain polyprenol was not detected. The Dura fruit has a thick shell and the fruits are large. Dura's fruit diameter is significantly distinguishable from other types (Basyuni et al. 2017b). This result indicated that the regulation of biosynthetic pathway of Dura fruit type might differ to the fruit type of Pisifera and Tenera (Swiezewska and Danikiewicz 2005).

As shown in Figure 1B, the Pisifera composition of polyprenol and dolichol was different in comparison to Dura. The differentiation of carbon-chain patterns between Lame and Yangambi was not detected. Shorter carbonchain of polyprenol was $\left(\mathrm{C}_{50}-\mathrm{C}_{60}\right)$ which is similar to Dura, also found in Pisifera. Bombiprenone compound identified in this fruit type. The main carbon chain in Pisifera was shorter polyprenol $\left(\mathrm{C}_{50}-\mathrm{C}_{60}\right)$, longer polyprenol $\left(\mathrm{C}_{90}-\mathrm{C}_{100}\right)$, and dolichol $\left(\mathrm{C}_{85}-\mathrm{C}_{100}\right)$.

The polyisoprenoid family in Tenera fruit type (Figure 1C) was also differentiated compared to fruit type of Pisifera and Dura. Both Lame and Yangambi presented a similar pattern. Fruit type of Tenera has short-chain of polyprenols $\left(\mathrm{C}_{45}-\mathrm{C}_{60}\right)$ which called as ficaprenol and much longer-chain polyprenols $\left(\mathrm{C}_{95}-\mathrm{C}_{105}\right)$. Dolichol of Tenera was $\left(\mathrm{C}_{85}-\mathrm{C}_{110}\right)$. The primary molecule of polyprenols was $\left(\mathrm{C}_{45}-\mathrm{C}_{55}\right)$ and dolichol $\left(\mathrm{C}_{90}-\mathrm{C}_{100}\right)$ which indicating that Tenera is differently regulated both of polyisoprenoid in their biosynthetic pathways (Sagami et al. 1992). Tenera seed from the view of palm oil plantation was superior and most planted variety worldwide; it is a hybrid of parent Dura (female) and Pisifera (male) (Basyuni et al. 2017b). 


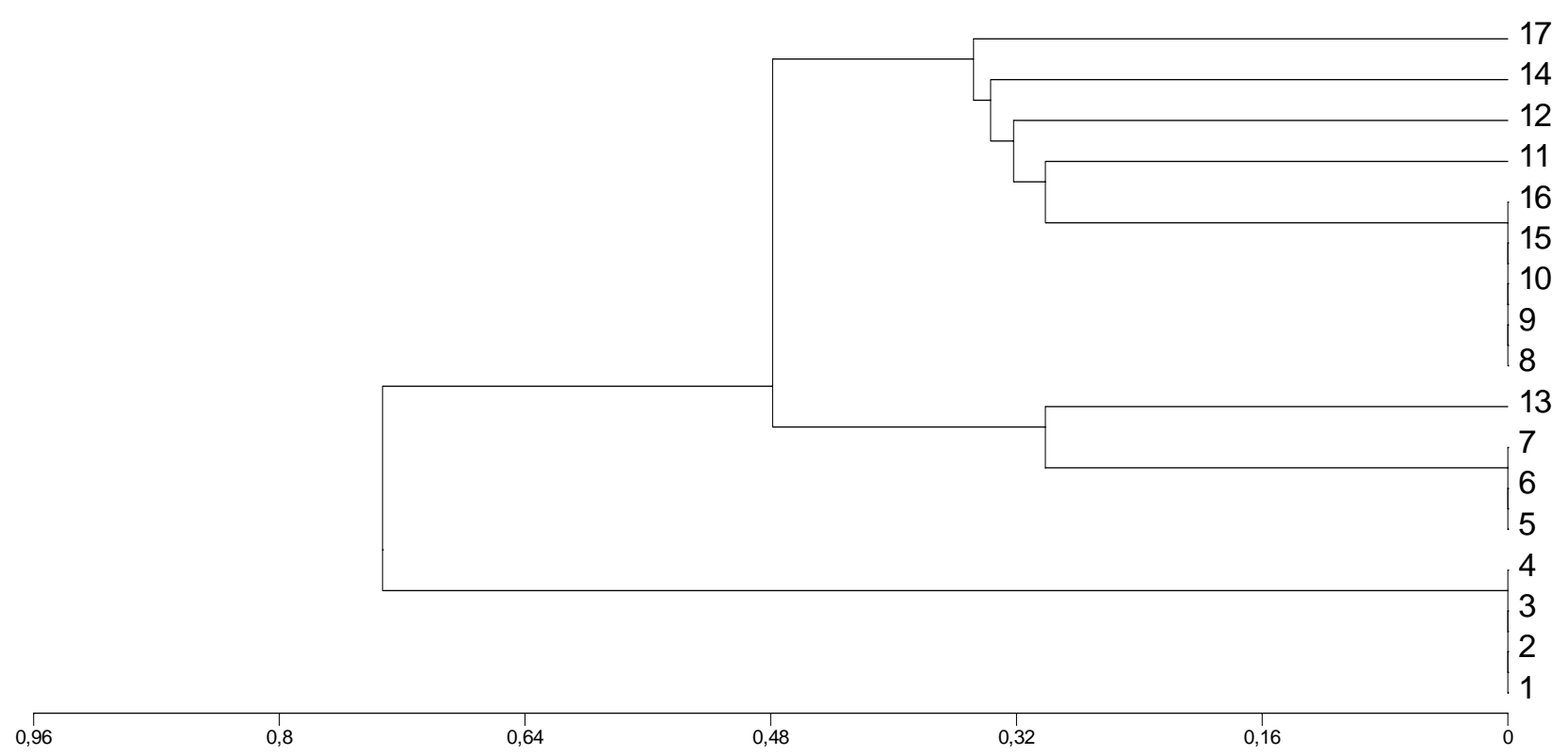

Figure 3. Dendrogram showing the relationship among 17 fruit types in palm oil from the fruit data of carbon-chain lengths of polyisoprenoids by $\log (10)$ transformation by Euclidean distance. Name of number for fruit type, see Table 2

The carbon chain polyisoprenoids from nurseries (Figure 2A) which are a hybrid between Dura and Pisifera has the composition of polyprenols $\left(\mathrm{C}_{50}-\mathrm{C}_{65}\right)$ and $\left(\mathrm{C}_{90^{-}}\right.$ $\left.\mathrm{C}_{100}\right)$, respectively, and dolichol $\left(\mathrm{C}_{85}-\mathrm{C}_{105}\right)$. This structure was almost similar to the carbon-chain pattern of Tenera fruit type. The primary carbon-chain molecule of the nurseries plants was polyprenol $\left(\mathrm{C}_{50}-\mathrm{C}_{60}\right)$ and dolichol $\left(\mathrm{C}_{90}-\mathrm{C}_{100}\right)$ respectively. This study was indicating that the nurseries plants used both compounds in their biosynthetic pathways to produce shorter polyprenols and longer dolichols which are close to Tenera (Tateyama et al. 1999; Basyuni et al. 2016, 2017a).

Furthermore the fruit shell samples of palm oil crossing of Dura and Pisifera occurring short-chain of polyprenol $\left(\mathrm{C}_{50}-\mathrm{C}_{60}\right)$ and longer polyprenol $\left(\mathrm{C}_{90}-\mathrm{C}_{100}\right)$ and dolichol $\left(\mathrm{C}_{85}-\mathrm{C}_{110}\right)$ (Figure $\left.2 \mathrm{~B}\right)$. Furthermore, the shell of Tenera $\mathrm{x}$ Tenera crossing has shorter polyprenols of $\mathrm{C}_{50}-\mathrm{C}_{60}$ and longer polyprenols $\left(\mathrm{C}_{90}-\mathrm{C}_{105}\right)$ and dolichol $\left(\mathrm{C}_{85}-\mathrm{C}_{110}\right)$. The pattern of carbon-chain of commercial seeds has two family composition of polyprenols $\left(\mathrm{C}_{50}-\mathrm{C}_{60}\right)$ and $\left(\mathrm{C}_{90}-\mathrm{C}_{105}\right)$, and dolichols $\left(\mathrm{C}_{85}-\mathrm{C}_{110}\right)$. These results are agreement with previous studies that the composition of polyisoprenoids is independently regulated in the plant kingdom, including in palm oil (Kurisaki et al. 1997; Tateyama et al. 1999; Basyuni et al. 2016).

The pattern of carbon-chain was analyzed and translated into binary data and visualized into dendrogram using UPGMA method. The dendrogram was expected to classify among the fruit type of Dura, Pisifera, and Tenera, respectively. Figure 3 shows that the samples of Dura were classified into a separate group with the similarity coefficient 0.78. Meanwhile, Pisifera also formed one group with similarity coefficient 0.32 and Tenera have similarity coefficient ranged $0.32-0.35$. On the other hand, the fruit type of Dura was detectable to identify comparing to Pisifera and Tenera. Furthermore, similarity coefficient of 0.78 indicating that Dura fruit type has farthest evolution range compare to others fruits-type.

The similarity coefficient of Tenera and Pisifera, which are close to each other, shows that both fruit types have some identical carbon-chain patterns, and the differences between them could only be identified by the molecules of polyprenols namely $\mathrm{C}_{65}$ and $\mathrm{C}_{105}$, respectively and having dolichol of $\mathrm{C}_{105}$. These molecules belong to Tenera and did not occur in Pisifera.

The samples of unknown fruit type (No. 16 and 17, Table 2) were clustered into Tenera's group as previously expected. This data indicated that samples number 16 and 17 as unknown fruit type could be confirmed as Tenera fruit type in the clustering analysis and carbon chain length. The present study demonstrated that 2D-TLC method could differentiate the fruit types of palm oil.

To conclude, 2D-TLC could be an alternative technique to identify fruit type of palm oil, in addition to molecular markers (Ritter et al. 2016). Diversity was noted in palm oil fruits: Dura had no carbon chain-length of polyprenol (>C90-C105) compared to Pisifera and Tenera. In Tenera polyprenols of $\mathrm{C}_{45}-\mathrm{C}_{60}$ and $\mathrm{C}_{90}-\mathrm{C}_{100}$ occurred, and dolichols of $\mathrm{C}_{85}-\mathrm{C}_{110}$, where polyprenols of $\mathrm{C}_{65}$ and $\mathrm{C}_{105}$ and dolichol of $\mathrm{C}_{110}$ were not detected in Pisifera. Our present data on palm oil polyisoprenoids confirmed the identification of palm fruit using 2D-TLC was clustered into appropriate palm fruit type and chemotaxonomically important. 


\section{ACKNOWLEDGEMENTS}

This work was supported in part by a Development of Science and Technology Grant (Ipteks 2016 No. 017/SP2H/LT/DRPM/II/2016) and a Masterplan for Acceleration and Expansion of Indonesia's Economic Development Grant (MP3EI 2017 No. 003/SP2H/LT/DRPM/IV/2017) from the Directorate for Research and Community Service, Ministry of Research, Technology and Higher Education, Republic of Indonesia. We thank PT Socfin Indonesia, Medan for their supporting the palm oil materials and laboratory.

\section{REFERENCES}

Basyuni M, Sagami, Baba S, Iwasaki H, Oku H. 2016. Diversity of polyisoprenoids in ten Okinawan mangroves. Dendrobiology 75: 167175 .

Basyuni M, Sagami H, Baba S, Oku H. 2017a. Distribution, occurrence, and cluster analysis of new polyprenyl acetones and other polyisoprenoids from North Sumatran mangroves. Dendrobiology 78: $18-31$.

Basyuni M, Amri N, Putri LAP, Syahputra I, Arifiyanto D. $2017 \mathrm{~b}$. Characterization of fresh bunch yield and the physicochemical qualities of palm oil during storage in North Sumatra, Indonesia. Indon J Chem 18: 182-190.

Chouda M, Jankowski W. 2005. The Occurrence of polyprenols in seeds and leaves of woody plants. Acta Biochim Pol 52: 243-253.

Ishiguro T, Morita-Fujimura Y, Shidoji Y, Sagami H. 2014. Dolichol biosynthesis: The occurrence of epoxy dolichol in skipjack tuna liver. Biochem Biophys Res Comm 451: 277-281.

Ishinaga M, Mukai K, Tanabe C. 1990. Changes in dolichyl fatty ester compositions during the germination of soybean embryos. Agric Biol Chem 54: 943-947.

Ishinaga M, Yamauchi T, Egusa K, Mukai K. 1992. Changes of dolichol and dolichyl fatty ester during development of soybean seedlings. Biosci Biotechnol Biochem 44: 45-50.
Kumari S, Priya P, Misra G, Yadav G. 2013. Structural and biochemical perspectives in plant isoprenoid biosynthesis. Phytochem Rev 12: 255-291.

Kurisaki A, Sagami H, Ogura K. 1997. Distribution of polyprenols and dolichols in soybean plant. Phytochemistry 44: 45-50.

Oil World. 2015. Oil World Statistic. ISTA Mielke GmBh. Hamburg, Germany.

Rincón SM, Hormaza PA, Moreno LP, Prada F, Portillo DJ, García JA, Romero HM. 2013. Use of phenological stages of the fruits and physicochemical characteristics of the oil to determine the optimal harvest time of oil palm interspecific OxG hybrid fruits. Ind Crops Prod 49: 204-210.

Ritter E, de Armentia EL, Erika P, Herrero J, Niggrum YP, Santika B, Endang Y, Sarimana U, Sembiring Z, Asmono D, Hernandez M. 2016. Development of a molecular marker system to distinguish shell thickness in oil palm genotypes. Euphytica 207: 367-376.

Rolinska M, Walinska K, Swiezwska E, Chojnacki T. 2002. Plant longchain polyprenols as chemotaxonomic markers. Dendrobiology 47: 41-50.

Sagami H, Kurisaki A, Ogura K, Chojnacki T. 1992. Separation of dolichol from dehydrodolichol by a simple two-plate thin-layer chromatography. J Lipid Res 33: 1857-1862.

Sakaihara T, Honda A, Tateyama S, Sagami H. 2000. Subcellular fractionation of polyprenyl diphosphate synthase activities responsible for the syntheses of polyprenols and dolichols in spinach leaves. J Biochem 128:1073-1078.

Schneider CA, Rasband WS, Eliceiri KW. 1992. NIH Image to ImageJ: 25 years of image analysis. Nature Methods 9: 671-667.

Swiezewska E, Danikiewicz W. 2005. Polyisoprenoids: structure, biosynthesis and function Prog Lipid Res 44:235-258.

Tateyama S, Wititsuwannakul R, Wititsuwannakul D, Sagami H, Ogura K. 1999. Dolichols of rubber plant, ginkgo, and pine. Phytochemistry 51: 11-15.

Wojtas M, Bieñkowski T, Tateyama S, Sagami H, Chojnacki T, Danikiewicz W, Swiezewska E. 2004. Polyisoprenoid alcohols from the mushroom Lentinus edodes. Chem Phys Lipids 130: 109-115.

Zhao Y, Williams R, Prakash CS, He G. 2012. Identification and characterization of gene-based SSR markers in date palm (Phoenix dactylifera L.). BMC Plant Biol 12: 237. 